\title{
OPPORTUNITIES TO IMPROVE INTERACTION BETWEEN EMPLOYEES AND EDUCATIONAL INSTITUTIONS
}

\author{
Boryana VARBANOVA \\ "Vasil Levski” National Military University, Veliko Tarnovo, Bulgaria, \\ varbanova_01@abv.bg
}

\begin{abstract}
In recent years, more and more countries have realised that investing in education is the key to their prosperity. At the same time, there is a trend towards an increase in youth unemployment in almost all European Union countries. On the one hand, the problems which have triggered this process arise from the higher education system, and on the other, from the relationship between the educational institutions and the employers. A subject of interest in this report is a study of how to stimulate interaction between employers, educational institutions and students. The attitude towards internships in different institutions and for different periods of time has also been studied.
\end{abstract}

Keywords: students, internship, university, employers, unemployment

\section{Introduction}

The higher education system is directly affected by the unfavourable processes which have been taking place in society over the past decade. On the other hand, it is precisely this education that can become a catalyst for the recovery because it supports, both in terms of personnel and ideas, the operation and development of the state and economy management systems. Knowledge is becoming a major growth factor in developed countries. It is perceived as a factor which is more important than natural resources, labour and physical capital.

The economy based on knowledge stands on the following four pillars:

- High-quality and well-trained human resources;

- Institutions providing a favourable environment for economic growth;

- Developed information and communication infrastructure;

- Policy directed towards innovative development.

\section{Problems in the higher education system.}

Problems in the higher education system begin with the admission and continue in the system itself and at the graduation stage. They are directly related to the lower quality of secondary education, the accessibility of foreign universities and the demographic crisis, which results in a lower level of student applicants.

The very system of higher education is poorly funded. The number of universities is constantly increasing, in inverse proportion to the number of students [6]. For the most part, universities have outdated and poorly maintained facilities as a result from scarce funding. With respect to student training, the employers' opinion and requirements are rarely taken into account as regards the need for specialists with certain qualifications, knowledge and skills. This in turn leads to high levels of unemployment among young people who have just graduated. 


\section{The problem of "youth unemployment".}

According to the National Employment Agency newsletter concerning the state of the labour market [4] in October 2017, just over half of the registered unemployed starting from the beginning of 2017 have secondary education, about $30 \%$ are mainly with primary education or lower, and less than $20 \%$ have higher education. An unfavourable trend is that the majority of the newly registered graduates have just completed their higher education, which points to serious gaps in the communication between educational institutions and employers [7]

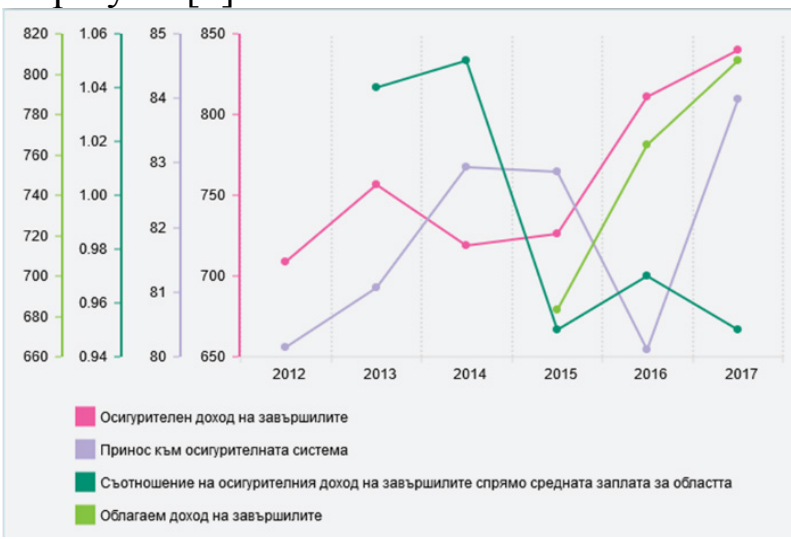

Figure 1: Income of university graduates - first occupied position [6]

The reasons for the increase in youth unemployment can be as follows[2]:

- education that does not correspond to the labour market;

- concentration of the main group of students in a limited number specialties;

- difficulty in starting the first job;

- low payment;

- the desire of young people to migrate after completing their education in search of better working conditions and successful realisation.

How can the problem of youth unemployment be solved?

The right approach is to observe the fundamental economic principle that the demand determines the supply. The solution to the problem goes along two strands:
1) pursuing a purposeful state policy regarding the state-funded specialties which universities provide training in;

2) improving the communication between the labour market and the education system.

We have focused on the second approach.

\section{Cooperation between universities, employers and students.}

The labour market is the main consumer of the educational product of higher education institutions. The main task of the universities is to prepare their trainees to cope with the requirements of businesses and their future professional realisation. In foreign practices, this connection is carried out by conducting internships and practices in organisations whose area of activity is close to the specialty, which students are taught in. More and more developed countries are moving towards the introduction of the so-called "dual education" [3]. Dual education curricula include both the standard theoretical training and the internship in an enterprise depending on the specialty. The benefits of such a form of learning are undoubtedly many, especially for the learners themselves, who, in addition to receiving payment (usually between a third and a half of the usual salary), also gain practical experience. As a result, they are trained before going on the labour market, which allows for getting a better job against higher pay. On a larger scale, the dual form of education plays an important role in the economy of the country that implements it, and has a direct impact on the reduction of youth unemployment with all the benefits that follow. A number of European countries have successfully applied this model. Germany, Austria and Switzerland are the countries with which dual learning is usually associated. These are also the countries with traditionally the lowest youth unemployment. The dual system is also known in a number of other countries, such as Denmark, the Netherlands, Hungary, Croatia, Australia, and China. 


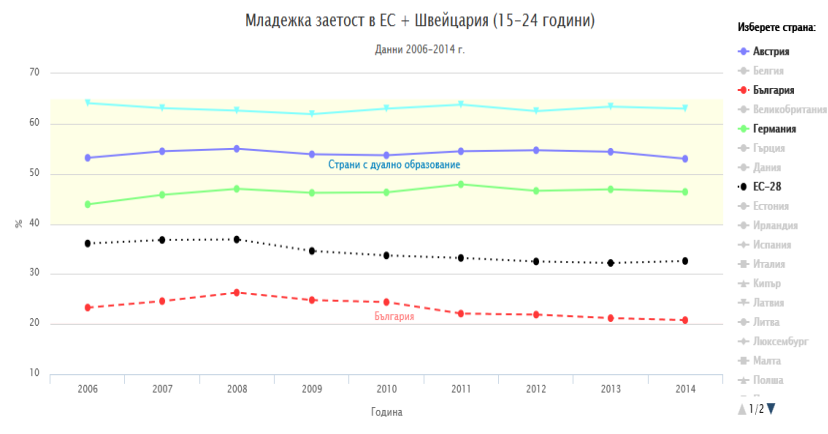

Figure 2: Youth unemployment and youth employment in the EU for ages between 15 and $24[3]$

These graphs clearly show that Switzerland, Germany and Austria are the countries with the lowest levels of youth unemployment. The values for 2014 there are $7.5 \%, 7.7 \%$ and $10.3 \%$ respectively, with an average of $22.2 \%$ for the EU and $23.8 \%$ for Bulgaria. The levels have been kept low throughout all the years under review, even during the crisis. The Netherlands, Denmark and Malta also achieved strong results. Countries such as Greece, Spain and Portugal remain at the other end.

Typically, internship programs begin in the third year of the Bachelor's degree course of training. At this stage, the trainees have demonstrated their learning abilities, but they also have enough time to refine before starting an active job. Such relationships are beneficial to both parties - interns accumulate invaluable experience, and employers have the opportunity to fill out their organisations with employees who have observed them perform in a real working environment. The main problem for students in participating in such practices is that in most cases they are not remunerated or it is minimum.

\section{Particularities in the implementation of internship programs in the Republic of Bulgaria.}

Organising and conducting voluntary student internships has started developing relatively recently in Bulgaria. Voluntary student internships are defined as work done on the part of a student for a short period of time (usually between terms for no more than three calendar months) under the direction and control of an employer in order for the student to acquire practical skills and experience in a professionally chosen area, which in most cases is related to the student's specialty at the university. As this matter is relatively new, there is still a lack of a comprehensive and detailed legal framework concerning student internships. There is a distinction between compulsory internships that are part of the academic program of students in a number of specialties, and voluntary internships where the main driving force is the student's initiative and desire. There is also a difference between the offered internships in the state administration, in business organisations and in non-profit organisations, especially in view of the specifics of the employer.

The legal framework does not yet make a clear distinction between the listed types of student internships. At present, there are only separate regulations in the Republic of Bulgaria that regulate the public relations in terms of student internships in a particular filed or type of institution.

Even though there is no explicit regulatory framework in the field, the principles of civil and labour law suggest that the trainee's interest in acquiring practical experience and skills in a professional area is guiding in the legal relationship. The employer, on the other hand, invests in the qualification of a prospective employee rather than receives qualified and full-time wage labour, and does not have to pay the usual remuneration for the profession to the trainee. In this sense, the issue of the payment of remuneration for the length of internship service comes secondary. The practice in Bulgaria, according to which employers on internship programmes usually pay their trainees' wages in minimum size, is then objectively reasonable.

Relationships between students and the university concerning internships are limited to whether the particular university 
encourages in some form the students' accumulation of practical skills and experience on a voluntary basis and in addition to the education they received through the university academic syllabi. There is a variety of possible forms of encouragement: establishing career centres, concluding framework agreements with employers for summer student internships, recognising summer internships as academic credits under the introduced credit system of education, including the summer internships as an additional qualification in students' postgraduate diplomas, etc.

At present, the acts regulating these relations are internal to the university, adopted on the basis of the legal principle of academic autonomy of higher education institutions in Bulgaria. The most commonly used form is the regulations for the structure and activity of the respective university or faculty. A great number of the universities have not yet settled this new issue in their internal regulations. The university-employer legal relationship is also important. It is also not explicitly regulated in the Bulgarian legislation and is regulated mainly on a contractual basis. In this relation, the Obligations and Contracts Act is applied, as well as the tax laws as far as they regulate the tax concessions for the benefit of employers in the case of investment of funds for the promotion of education. Last but not least is the role of the state in the initiatives to create a longterm practice of student internships. At the moment, the state is primarily committed to regulation and promotion. The main regulatory act in this respect is the Employment Promotion Act.

At the end of 2016, the Bulgarian Industrial Association (BIA) conducted a large-scale study on the attitude towards internships and their efficiency, involving more than 500 employers and more than 500 trainees [5]. $89 \%$ of the Bulgarian employers are offering or have offered internships, $26 \%$ of them have their own internship program, and $57 \%$ accept interns without having adopted a specially designed program. Only $4 \%$ admit that they only use state-funded internship programs. In the last 12 months, $71 \%$ of the interviewed employers have received trainees, and the remaining 29\% explain their decision not to provide internships with: lack of financial opportunities (22\%); ambiguities in labour and social security legislation (16\%); lack of quality candidates for internship (13\%); frivolous attitude of trainees to the tasks assigned to them (12\%); lack of appropriate conditions $(11 \%)$; unjustified claims by trainees $(9 \%)$; lack of motivation of their employees to work with trainees $(8 \%)$; lack of appropriate mentors (7\%); lack of information on how to appoint a trainee, lack of appropriate activities to be assigned to a person with little experience and short service in the company $(2 \%)$.

In terms of pay, $47 \%$ of the trainees and $37 \%$ of the employers believe that internship labour should be paid only for longer periods of service - over three months. None of the trainees surveyed agree to work without pay, while $17 \%$ of the employers have the opposite opinion. At the same time, $55 \%$ of the trainees declare that they have not received any payment for their labour during an internship, $25 \%$ have worked under a contract of employment, and $20 \%$ - under a civil contract (hourly pay).

Employers usually compensate for the lack of opportunities for paying internships by providing certain benefits. The most common ones are technical equipment (33\%), training (31\%), free food (10\%), company mobile phone $(7 \%)$, working clothes $(7 \%)$, medical care $(7 \%)$ or company transportation $(5 \%)$. In the vast majority of cases, the daily occupancy of one trainee is between 4 and 8 hours, and $7 \%$ of the trainees and $6 \%$ of the employers report an occupation longer than 8 hours per day. 


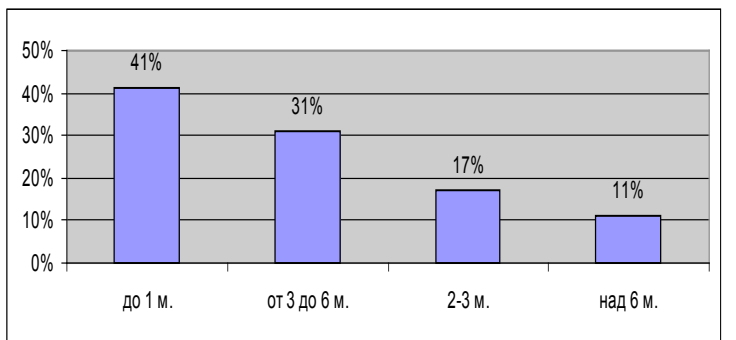

Figure3: Duration of students' internships

When asked the question "Have you used the opportunities provided by state-funded internship programmes in the last 12 months?", every second employer responds negatively, only $11 \%$ - affirmatively, and another $11 \%$ express their intent to use them although they have not done so yet. $21 \%$ say they have no information about such programmes, and in $4 \%$ of the cases the answer is "I'm not interested".

Only $6 \%$ of the employers and $2 \%$ of the trainees do not approve of the idea of state funding of internships.

\section{Conclusion}

In conclusion, we can say that the interaction between employers and educational institutions can be improved by relying on continuous interaction through the organization of internship programs.

\section{References}

[1] Petrova, E., Motivation for Education and Learners' Satisfaction with the Choice of Military Specialisation or Civilian Specialty, The $23^{\text {rd }}$ International conference Knowledge-Based Organization, Sibiu, Conference proceedings ISSN 1843-682X, ISBN 978-973-153-274-5, 15-17 June 2017, Vol. XXIII No 2 2017, pp. 355-360.

[2] Varbanova, B, Vicious circle of subsidized employment, International Conference Knowledge-Based Organization, Land Forces Academy "Nicolae Balcescu" SibiuRomania

[3] https://www.infograf.bg/article/1456353564000

[4] www.az.government.bg

[5] www.bia-bg.com

[6] http://rsvu.mon.bg

[7] www.nsi.bg 